\title{
Political Representation in Times of Bailout: Evidence from Greece and Portugal*
}

\author{
by Julian Borba \\ Universidade Federal de Santa Catarina, Brazil
}

(FREIRE, André; LISI, Marco; ANDREADIS, Ioannis and VIEGAS, José Manuel Leite (2016), Political representation in times of bailout: evidence from Greece and Portugal. London and New York: Routledge)

I

$\mathrm{t}$ is a commonplace among political scientists to assume that economy matters! Different theoretical perspectives of the discipline have committed themselves to finding the links between the economic and the political phenomena. One way of investigating this relationship is through systematic empirical studies that seek to control the effects of different economic factors on the explanation of political phenomena. It is this what the work organized by André Freire, Marco Lisi, Ioannis Andreadis and José Manuel Leite Viegas proposes to do.

Taking the economic crisis that first hit the United States in 2008, and soon after reached Europe as starting point, and taking the comparison between the Portuguese and the Greek cases as empirical object, the authors investigate the impact of the crisis (and the responses to it) on issues such as: changes in political representation standards (central dimension of the work) and the relationship between the crisis and the political legitimacy, as well as the analysis of more specific issues such as the impact of the crisis on forms of conducting election campaigns and on the ideological space.

Under the theoretical debate, the central concept of the study, as printed in the title itself, is the political representation. Therefore, the authors fundamentally mobilize the literature that interprets the representation as 'congruence' between voters and representatives, originally formulated by Miller and Stokes (1963).

(*) http://dx.doi.org/10.1590/1981-38212016000200010 
Empirically, this perspective measures the phenomenon from the correspondence between the preferences of voters and legislators. The basic axiom is that the closer the preferences of both are, the more representative the political system is ${ }^{1}$ (FREIRE et al;, 2016, p. 04). Other theoretical dimensions are also mobilized, in particular the concept of democratic legitimacy, based on the concepts of diffuse and specific support (EASTON, 1965) (chapter 05). Issues as the ideological space and its dimensions (Chapter 06) and the personalization of politics (Chapter 07) are also discussed. In addition, a theoretical question that is implied, but little discussed in the book, is related to the debate on political parties and their transformations in contemporary democracies.

The work is a compilation, distributed in seven chapters, written by researchers from Portuguese and Greek institutions. Originally, the book's chapters were part of a special issue of the journal South European Society and Politics, volume 19, issue 4 (December 2014).

The first chapter is a great introduction that contextualizes the research problems, the main results, in addition to detailing the adopted methodological procedures. For contextualization purposes, it is noteworthy that the crisis in question is related to the impact of the banking system collapse in the United States (2007-08) that affects the entire European community. Depending on the answers that the national units initially gave to the crisis, the existing imbalances in public finances of some countries (particularly in southern Europe) widened, leading to what is conventionally called 'sovereign debt crisis in southern Europe' (FREIRE et al., 2016, p. 01). This made, first Greece (in 2010), and then Portugal (in 2011), to ask international bodies such as the European Commission, the European Central Bank and the International Monetary Fund (the Troika) for a 'rescue' package. The intervention of these institutions promoted profound adjustments in the economies of the two countries in terms of economic recession, rising unemployment and promoting the implementation of reforms aimed at the market.

Even without a general hypothesis to guide the study, it is implicit, in the argument of the authors, that the empirical expectation is that the crisis has

\footnotetext{
${ }^{1}$ For space reasons, we here simplify a broad theoretical and methodological debate on political representation as 'congruence'. For a literature review, see the recent work of Carreirão (2015).
} 
decreased the congruence between voters and their representatives in both countries, having also negatively affected the legitimacy standards of the democratic regime itself. Similarly, the authors realize in the crisis and in the answers given by the political system some clues to understand the emergence and expansion of new political parties (especially the extreme right and extreme left parties in Greece), as well as of the growth of the so-called Euroscepticism.

As for the methodological dimension, it is important to point out the author's choice to use a comparative approach, justified by their 'similarities' and 'differences' (PRZEWORSKI and TEUNE, 1970): similarities as Portugal and Greece are the most affected countries by the crisis of the European community and also the nations that asked the 'troika' for financial rescue, besides being countries that share great similarities in demographic, political and economic terms. On the side of the differences, the two countries had different economic and political responses to the crisis: in economic terms, while Portugal partially restructured its finances, Greece did not succeed in this regard. In political terms, the emergence of extremist parties was something restricted to the Greek case. The size of public protests was much stronger in Greece than in Portugal, too.

Also on the methodological aspect, it is worth noting which might be the major contribution of the study: the chance to study the problem as a 'quasi experiment'. This was possible thanks to the availability of systematic researches (with similar questions) with voters and representatives from before the emergence of the crisis (2008 and 2009 data) ${ }^{2}$. The same surveys continued to be made after the external intervention period, which allowed the authors to isolate the effect of 'crisis' and 'austerity policies' on the opinions, attitudes and behavior, both of the mass public and their representatives.

Going to the content of the other chapters, the first four address issues related to the relationship between crisis, austerity policies and political representation. With the exception of Chapter 02 , which deals only with the Greek case, all the others are comparative studies. We will not go into the details of each of these chapters; we will focus on their general conclusions. The first is that the crisis

\footnotetext{
${ }^{2}$ Research carried out under the project "Elections, Leadership and Accountability: Political Representation in Portugal in a Longitudinal and Comparative Perspective". Available at http://er.cies.iscte-iul.pt.
} 
and the austerity policies have decreased the degree of congruence between voters and representatives, and that this incongruity is more manifest in Greece than in Portugal. When congruence is analyzed around specific issues, it is possible to verify, for example, that it is higher among voters of the parties in government than in opposition voters in both countries, with regard to the acceptance of the memoranda of understanding with the troika. There are also similarities related to the expansion of 'Euroscepticism' in both countries, which is also a source of policy incongruity, because that phenomenon is more noticeable in the electorate than in its representatives. Even so, the Euroscepticism is more pronounced in Portuguese than in Greek voters. There are differences between countries in the agreement on the need for negotiating public debt, which is more consistent among Greek than among Portuguese voters and representatives. An issue which is a source of incongruity between Greek voters, but that has not been studied in the case of Portugal, is immigration. In the Greek case, it is there where the greatest distance between deputies and voters lies (Chapter 02). In addition, the positions of voters on immigration are not directly related to their ideological positioning as would be expected, leading the authors to discuss the multidimensional aspect of representation:

In this respect, the analysis of the Greek case highlights the importance of exploring issue dimensions beyond a simple left-right ideological dimension. The observed substantial variation in congruence, across parties and issue preferences in Greece, reinforces the view that the dimensionality of political contestation is not reducible to a single ideological dimension. This is particularly true at times of crisis and high political volatility, when positioning on austerity, immigration and European integration moves to centre stage in the dynamics process of linkage between represented and representatives. Our analysis reveals that there is no necessary correlation between the various dimensions. For instance, there are voters displaying pro austerity and antiimmigration preferences who position themselves on the ideological 'left', while others placing themselves on the 'right' hold strong anti austerity positions (...) Our study is of significance in pointing to complexity of representation - to the heterogeneity of positions across multiple dimensions and across and within parties - in times of crisis which simultaneously encompasses representational congruence and incongruence (FREIRE et al., 2016, p. 39).

This finding has significant analytical implications because much of the debate about representation uses the matrix left/right as a proxy of the political 
position of the voters and representatives on different themes. The Greek case shows that, especially in times of crisis, the opinions on political issues tend to be ideologically consistent.

Another aspect covered by the book concerns the democratic legitimacy (Chapter 05). Teixeira, Tsatsanis and Belchior (2014) take the Eastonian distinction between diffuse (democracy as a principle) and the specific (procedures and typical actors of democracy) support as their starting point to see if the economic crisis was jeopardizing the support for democracy in both countries. The authors found a decline in the specific support for the democratic regime, which may be related to the emergence of the economic crisis. In the Greek case, there is a decline under the diffuse support, if 2008 compared to 2012; this was not identified in the Portuguese case. Considering what the literature on democratic legitimacy points out, we have a dangerous situation for the future of democracy in Greece here, where the democratic coexistence bases begin to be put in check. In concrete terms, such attitudes of voters may be materializing, for example, the support for anti-system parties, as can be seen in the case of the "Golden Dawn", with all its "anti-democratic credentials" (FREIRE et al., 2016, p. 102).

Finally, the last two chapters study the impacts of the crisis on both the ideological space and the campaign strategies. On the first question, the authors point out a change in the content of ideological spaces in the two countries (with the addition of issues related to crisis, economic intervention, austerity and the European Union to the ideological left/right division). Left and right gained new ideological content, particularly in the context of the Greek electorate, where cultural issues emerged, forming a two-dimensional ideological space: economic/cultural (especially those derived from the issue of immigration, as pointed out above). In relation to the political campaign standards, there were no major changes compared to the period before the crisis, especially in the aspect raised by the authors related to a possible expansion of the 'personalization of campaigns'.

Once the considerations about the structure of the collection were made, it is now time to briefly reflect on its contribution to the contemporary debate of Political Science. I believe its first major contribution is in the methodological framework, in particular the importance of the systematic study of the longitudinal 
character of national realities. It was only due to the existence of consolidated research groups, applying annual surveys replicated with the same questions to voters and representatives, over several years, that discussing the issue of the impact of the crisis on the attitudes and behaviors of both segments was possible. So, it was not the situation that led the research agenda, but rather a systematic research agenda that made analyzing the impacts of the situation possible.

In the empirical aspect, the study dealt with some of the great debates of recent literature on political behavior. When examining the factor 'economic crisis' and assessing its impact on patterns of congruence between voters and representatives, on patterns of competition and on the democratic legitimacy itself, the authors inserted a procedural dimension in policy analysis, and were able to measure (or at least tried to), the effects of short-term dynamics ('earthquake crisis' in the words of the authors) on the patterns of political behavior, and on the configuration of the political institutions. Here, the Greek case is where the causal links between these dimensions seem more visible.

The major limitation of the work seems to be on the theoretical dimension. Although worked throughout the book, the theoretical impact of empirical findings is little problematized. Based on the novelty of the subject and on the empirical results achieved, some issues could be more thoroughly developed. The discussion with the literature that deals with the two pillars of the book - 'crisis' and 'representation'- is very little explored. This remark, however, in no way compromises the quality of the work, which has much to contribute to the development of the studies on the political behavior in the Brazilian political science, especially in a context where the economic and political 'crises' are materializing in large proportions among us!

\section{References}

CARREIRÃO, Yan S. (2015), Representação política como congruência entre as preferências dos cidadãos e as políticas públicas: uma revisão da literatura internacional. Opinião Pública. Volume 21, № 02, pp. 393-430.

EASTON, David. (1965), A Framework for Political Analysis. New Jersey: PrenticeHall, Inc. 320pp. 
FREIRE, André; LISI, Marco; ANDREADIS, Ioannis and VIEGAS, José Manuel Leite (2016), Political representation in times of bailout: evidence from Greece and Portugal. London and New York: Routledge. 164pp.

MILLER, Warren E. \& STOKES, Donald E. (1963), Constituency influence in Congress. American Political Science Review. Volume 57, № 01, pp. 45-56.

PRZEWORSKI, A. and TEUNE, H. (1970), The logic of comparative social inquiry. New York: Wiley-Interscience. 153pp. 